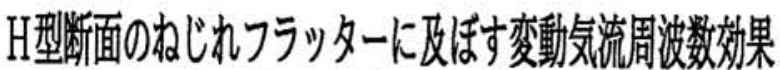

Frequency Effect of Fluctuating Flow on Torsional Flutter of 2-D H Shaped Models

\author{
松本 勝・1 \\ Masaru MATSUMOTO \\ 伊藤裕一 $\cdot 3$ \\ Naruhito SHIRAISHI Yuichi ITOU
}

晹川雅之・4

Masayuki YUKAWA

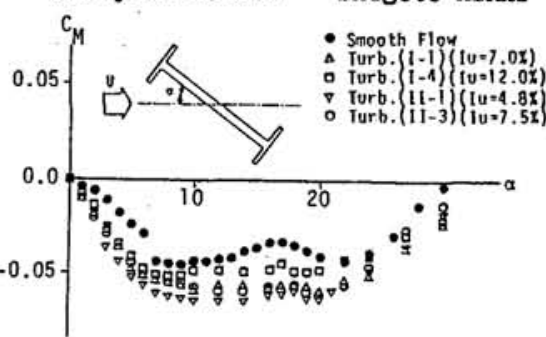

1.まえがき 気流の乱れが各種空力現象に及ほす影響（乱 流効果) を明らかにすることは、搼造物の空力挙動に対する安全 性を、より現実に近い形で伻価できるという点で、非常に重要な ことと考えられる。従来、乱流効果に関する研究では、乱流特 性を表すパラメータとして、主に乱れの強さや乱れのスケールが 多く用いられて来たが、本研究では乱流が様々な周波数を持つ、 流れの集合体であるという傾面から、H型構造断面の、格子乱流 と、眽流 (主流方向にわずかな単一周期変動を有する気流) 中に おける空力諸特性を対比することにより、乱れの周波数効果につ いて検討を加える。

2. 静的特性 Fig.1 4k、断面辺長比 $B / D(B$ :幅員、 D: 析高 ) $=3,9.4$ 両 $\mathrm{H}$ 型断面の、一様流と格子乱流、脈流中における迎角 一モーメント係数曲線の比較を示す。 $\mathrm{B} / \mathrm{D}=3$ 断面では、乱流並び に高周波数の脈流 $(\mathrm{FpD} / \mathrm{U}=0.40,0.50)$ 中において、モーメント係 数勾配の絶対值 $|\mathrm{dC} / \mathrm{d} \alpha|$ が大きくなる傾向がみられる。これ は中村らの実験結果 1 , との比較から、連行作用の促進により、見 かけ上、断面辺長比が大きくなったためと考えられる。一方、B/ $D=9.4$ 断面では、一様流中において負であるモーメント係数勾配 が全ての乱流中、並びにこの断面の剶離せん断層不安定性増幅域 に相当する、臨界周波数 $\mathrm{FpD} / \mathrm{U}=0.25$ をピークとした脈流中で正の 値に移行する。また、乱れ強さがほほ等しい、乱流(I-1)と（II-3 )では、比較的低周波数成分のパワーが大きい前者の方がモーメ ント係数の值が大きい。

Fig. 5 6に、油膜法による流れの可視化実験の結果を示す。 $\alpha$

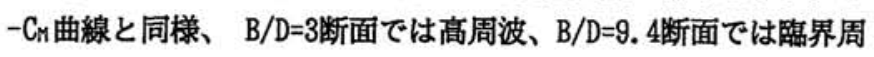
波数の脈流中で、乱流中と同傾向の結果が現れている。

3. 動的特性 無次元風速 $U / f B=7.5$ における、断面辺長比と、 非定常空気力係数 $\mathrm{A}_{2} \cdot$ との関係を、一様流及び乱流 $\mathrm{I}-4(\mathrm{Iu}=12 \%)$, II-1 ( Iu=4.8\%) 中において測定した結果をFig. 5 に示す。（ $\mathrm{A}_{2}$ * の值の大小は、俣れフラッターの刢振力の大小に対応する。）

一様流中ではB/D $=5.5$ 断面の $\mathrm{A}_{2} \cdot$ が最大となっている。 *1 京都大学・土木工学科, 助教授 *2 京都大学・土木工学科, 教授 Assoc. Prof., Dep of Civil Eng., Kyoto Univ. *3 京都大学・土木工学科, 大学院 Prof., Dep of Civil Eng., Kyoto Univ. *4 住友金属工業(株)

Graduate Student, Dep. of Civil Eng., Kyoto Univ. Sumitomo Metal Industry Ltd. 


\section{乱流II-1 (Iu=4.8\%)が各断面の非定常空気力} 係数 $\mathrm{A}_{2} ・$ に与える影䛠は、連行作用の促進によ り、見かけ上、断面辺長比を伸ばしたような効 果、すなわち、 $B / D=5.5$ より鈍い $(B / D<5.5)$ 断面 では、乱流中で $\mathrm{A}_{2} \cdot$ の值が大きくなり、不安定 化傾向を、これに対し、偏平な $(B / D>5.5)$ 断面 では、乱流中で $\mathrm{A}_{2} \cdot$ の值は小さくなり、安定化 傾向を示す。ここで、 $B / D=9.4$ 断面のモーメント 係数勾配は、乱流で正の値を示したが、振れフ ラッターは乱流中においても発現しており、こ れら偏平な断面の掋れフラッターの発現機構は、 流れの遅れの効果など非定常的要素が強いもの と思われる。これは、別途測定された振動変位 に対する断面後縁の变動圧力の位相遅れが、非 常に大きいことによっても確認できる。

Fig. 6 に、一様流と 2 種類の脈流、すなわち 臨界周波数を持つ眽流と、それより高周波数の

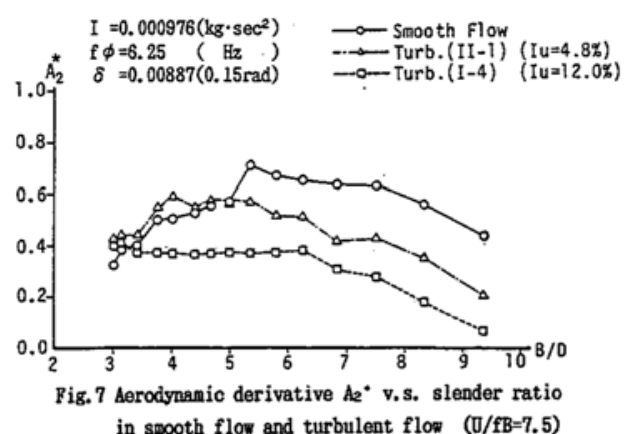

a) in Turbulent Flow

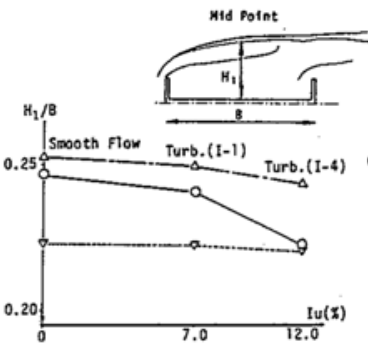

b) in Pulsating Plow

Fig. 5 Mid-point apparent separation bubble width $H_{4}$
for $B / D=3$ H-section

a) in Turbalent Plow

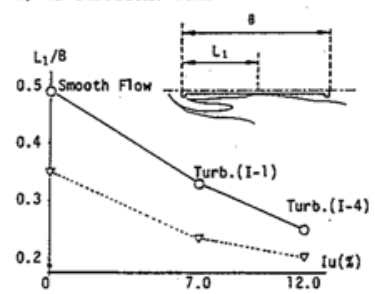

b) in Pulsating Plow

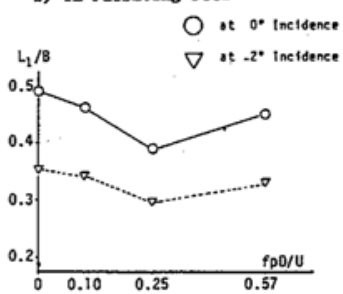

Big. 6 Apparent reattachment length $L_{4}$ for $B / D=8.4$ H-section

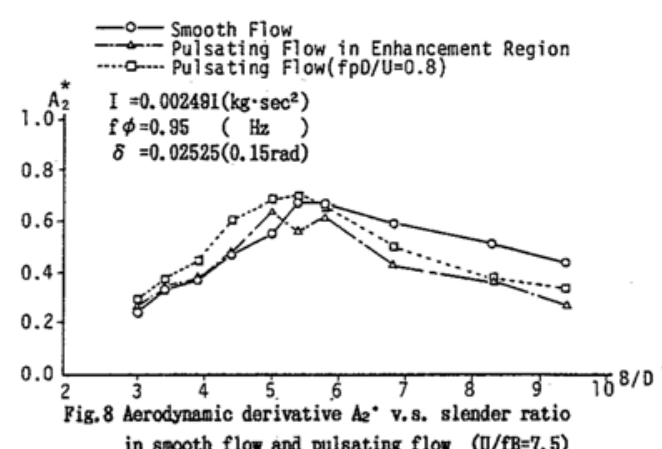

脈流 $(\mathrm{fpD} / \mathrm{J}=0.8)$ における、断面辺長比と非定常空気力係数 $\mathrm{A}_{2} \cdot$ の関係を示す。脈流が、各断面の $\mathrm{A}_{2} \cdot に$ に える影響は、乱流II-1(Iu=4.8\%)が $\mathrm{A}_{2}$ *に与える影響と類似している。しかし、その影響が顕著に現れる脈 流は、断面辺長比により異なる。すなわち、鈍い断面(B/D<5.5)には、臨界周波数を有する脈流は、ほとん ど影響を与えないのに対し、高周波( $\mathrm{fpD} / \mathrm{U}=0.8)$ の脈流は大きな影響を示し、不安定化奻果を促す。一方、偏 平な断面( $\mathrm{B} / \mathrm{D} \geqq 5.5)$ には、両者ともに影響力を有しており、2つの効果が存在しているようである。しかし、 その程度は臨界周波数を持つ脈流の方が大きい。

4. 結論. 乱れの周波数奻果としては、次の 2 つの周波数領域が大きな影翠力を有していると考えられ る。一つは、剥離せん断層の不安定性増幅領域（臨界周波数）を超える高周波数領域であり、もう一つは、 剥離せん断層の不安定性を強く增幅する周波数領域（踇界周波数）である。そして前者は、比較的鈍い物体 に対し大きな影響をもたらし、連行作用促進効果を強める。一方、後者は、比較的偏平な断面に対し大きな 影響力を有する。さらに、臨界周波数を超える高周波数成分の気流変動は、連行作用を促進するという意味 で、小スケール効果と、また剝離せん断層の不安定性増幅領域（臨界周波数）の気流変動は、渦放出などの 非定常な特性に影響をもたらすという意味で、大スケール効果とそれぞれ対応づけられる。

参考文献 1）中村泰治 他, “矩形およびH型断面柱の空力 3 分力特性について”, 九州大学応用力学研究所 所報, 第40号, 昭和48年 


\section{トラス杕のフラッター振動特性てこ つけての基礎的研究}

Fundamental study on flutter characteristics of truss girder section

$\begin{array}{cll}\text { 松本 勝*1, 白石成人・2, } & \text { 辰巳正明・3, } \\ \text { Masaru MATSUMOTO Naruhi to SHIRAISHI } & \text { Masaaki TATSUMI } \\ \text { O平井滋登* }{ }^{4}, & \text { 伊藤裕一・4 } \\ \text { Shigeto HIRAI } & \text { Yuichi ITO }\end{array}$

1.はじめに吊橋が長大化するにつれ，上部構造の耐風性能を礶保することは極めて重要な問題と なる. その杵断面としては, トラス桁が通常広く採用されているが, それには発散型の空力振動であるフラ ッターが発生し, その振動特性はトラスの基本形状の他, 迎角やトラスに付加される添加物等の諸要因の影 響を複雑に受けるとされている. 筆者らは, 床版とトラス本体を分割した模型を用いて, 風洞実験によりト ラス称のフラッター特性について検討した" . 本研究は, その結果を踏まえつつ, 新たに主として種々の付 加物を加えることの効果や振動モードの影䈉等を実験的に調べたものである.

2. 実験方法風洞実験に用いた模型は, トラス杵の 2 次元部分模型であり, 管理路や公共添加物等 を一切設けていない場合（Type 0）を基本に変化させた（Fig. 1) . なお，文献 1) とは，床版端部の形状 に変更を加えている. 模型は, その重心位置を回転中心として, 1 自由度（ねじれのみ）あるいは 2 自由度 （曲げとねじれ）の弾性支持を行い，一样流中における振動応答を測定した. 模型の物理諸元は各ケースで ほほ共通の值となっている.

\section{3. 結果基本とした模型の状態 (Type 0)}

で，支持条件の连いによる風速一応答振幅図をFig.

2 (迎角 $0^{\circ}$ ) と 3 (迎角 $-3^{\circ}$ ) に示す. 迎角 $0^{\circ}$ におい ては，2自由度支持において発生していたソフトタ イプのフラッターが1自由度ではみられなくなった. しかし, 迎角 $-3^{\circ}$ では, 発現風速にやや違いはある むのの, ねじれ 1 自由度においても 2 自由度と同様
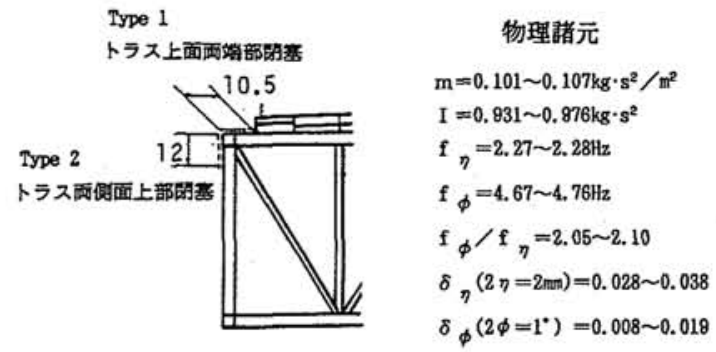
の応答を示している.
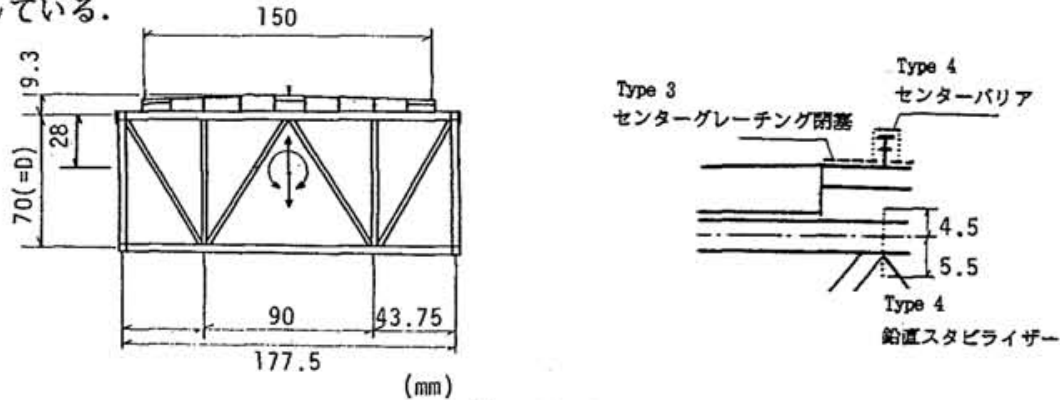

Fig. 1 トラス析模型概胳

*1 京都大学・土木工学科, 助教授 Associate Professor, Kyoto Univ.

*3 本州四国連絡橋公団設計部

Design Dept., Honshu-Shikoku Bridge Authority
*2 京都大学・土木工学科,教授

Professor, Kyoto Univ.

*4 京都大学,大学院生

Graduate Student, Kyoto Univ. 
次に,トラスの両側面上部を塞いだ場合 (Type 2) の応答をFig. 4に示す. 迎角 $-3^{\circ}$ においては, 無次 元風速6付近でねじれの卓越した限定型の振動が発 生した後, 測定範囲で定常振動の発生はみられない. 一方, 迎角 $0^{\circ}$ では, 先の限定型振動と同様の風速域 から振動が発生し，振幅が徐々に大きくなっている. このケースでは, トラスの充実率が増加することに より, その空力特性が充腹断面のそれに近づき, 洞 励振の発生が生じやすくなったことが考えられる. 迎角 $0^{\circ}$ における振動も発現風速がほぼ同じであり, 同様にまず渦励振が発生し, そこから振動が誘起さ れていった可能性が考えられる. なお, この場合に は, 無次元風速が約 20 以上で, ばねの途中に節ので きる高次の振動モードが発生し, 本来の振動より卓 越するような現象が認められた.この高次モードの 振動数が, 本来のねじれ振動数のおおよそ 3.2 倍で あることより, 高次の振動数による無次元風速約 6 という值に対応していることが考えられる，しかし， 本来の振動より卓越するに至った原因については明 らかではなく, 今後の検討課題である.

さらに, 種々のケースにおいて定常振動の発生が みられた限界風速と迎角の関係をFig. 5に示す. 実 施したケース中では, センターバリアと鉛直スタビ ライザーを共に設置した場合（Type 4) に振動の発 生がみられず, 最も安定となった.また, 全体的に は, 文献 1 ) の結果とは逆に負の迎角ほど不安定な 傾向を示し，床版端部の形状という小さな要因でも， フラッター特性には大きな影響を及ほしているもの と思われる.

\section{4. あとがき} 本研究では, あるトラス桁を 例としてとりあげ, そのフラッター振動特性の検討 を行った. その結果, 小さな形状の変化によってむ 特性が敏感に変化すること, 低風速域における振動 の発生には渦励振が大きく関わっている可能性があ ることなどが認められた. 今後は, 充腹断面のフラ ッターとあ対比しつつ, その発生メカニズムや制振 手法についての検討が望まれる.

\section{5. 参考文献}

1) 平井滋登,松本勝,白石成人,辰巳正明:トラス補 剛杵のフラッター特性に関する実験的研究, 土木学 会第44回年次学術講演会講演予定, 平成 1 年10月.

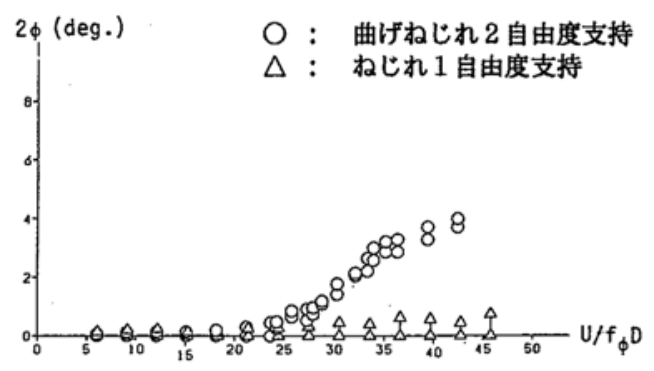

Pig. 2 風速一ねじれ応答振幅図 (Type 0, 迎角 $0^{\circ}$ )

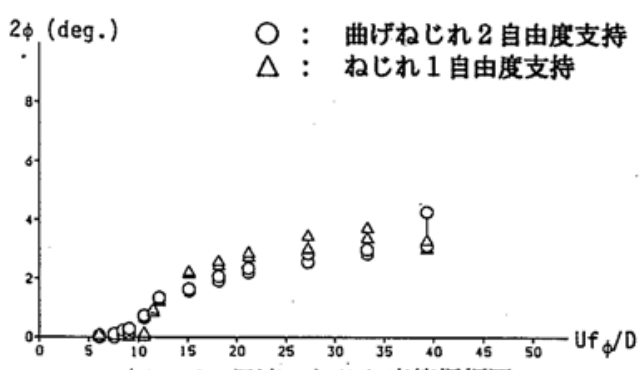

Big. 3 凰速一ねじれ応答振幅図

(Type 0, 迎角 $-3^{\circ}$ )

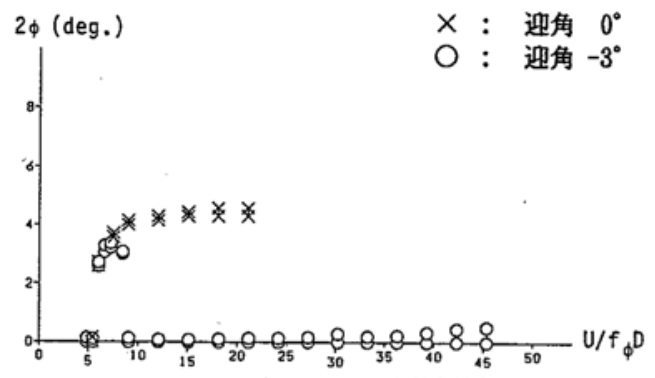

Pig. 4 風速一ねじれ応答振幅図

（Type 2，2 自由度支持）

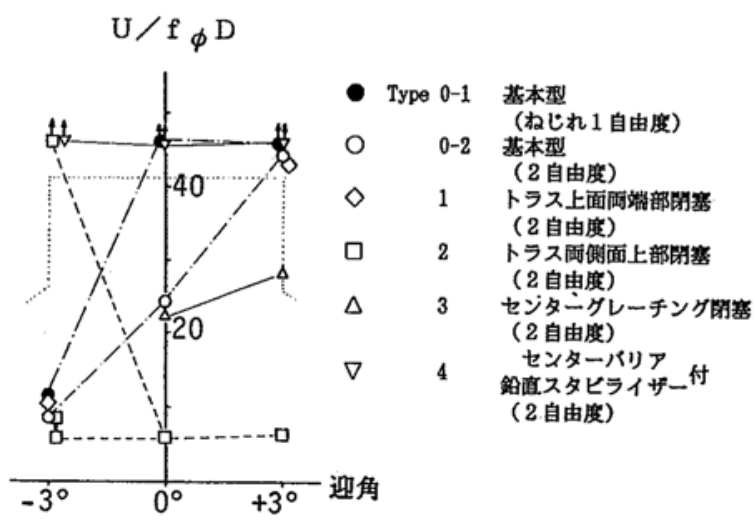

Fig. 5 定常振䡃に対する限界風速 
境界層乱流中における長大吊橋の鉛直・ねじれガスト応答の予測 Prediction of gust response of long-span suspension bridge under turbulent flow
岩本政已 $* 1$
藤野晹三
宮田利雄
篠泉 ${ }^{* 2}$
伊藤 學 $^{* 2}$
武田勝昭
M. IFAMOTO
Y. FUJINO I. SHINO
M. ITO
Y. HIKAMI
T. MIYATA
M. TATSUMI
M. TAKEDA

1、まえがき 明石海峡大橋箱析案（図 1）の三次元模型による二連の風洞実験を 行なった。一様流中のフラッター限界風速 については、20近いケースで総して誤差5\% 程度と高い精度で、部分模型実験より求め た動的空気力 (非定常空気力) 功らトリ ッブ理論により予测可能であるという結果 を得ている(文献 1)。

今回は境界屏乱流中のガスト応答に注目 し、応答の実験值を動的空気力と三分力係 数を用いて予㨽し、その信頼性を検証する。 2 .三次元模型 実験に用いたのは、弾 性三次元模型とタウトストリップ模型（図 2 、相似比はすべて $1 / 350)$ である。各々 について、Flatな断面とBluffな断面から なる変断面橋とBluff一椂断面橋がある。 3. 予湖方法 (1)部分模型実験 ( I H I) : 一様流中で部分模型を用いて、静的空気
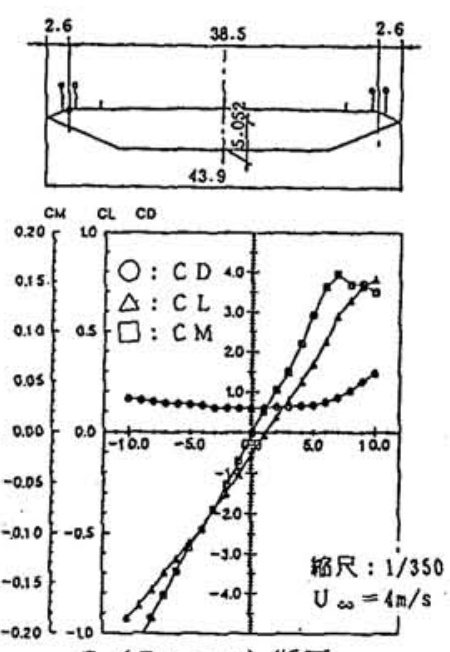

F ( F $\mid a t)$ 断面

力、及び強制正弦波加振法により動的空気 力を求めた。

(2)解析方法 : 動的空気力と、变動強制空気力 （バフェッティング外力）を考虑してモーダル方 程式を立てる。振動モードは、鈆直たわみの対称 一次 (21)、逆対称一次 (22) 及びねじれの対称 一次モード $(\theta)$ の 3 自由度系とした。ケーブル による空力減衰は無視し、静的ねじれ变形の橋軸 方向分布は三次元模型の実駼結果 (タゥト模型は 振動モード形) を使用した。各モードの固有振動 数 $\omega$ 、減衰定数 $\zeta$ 各模型の実倹値を用いた。最 終的な運動方程式を以下に示す。

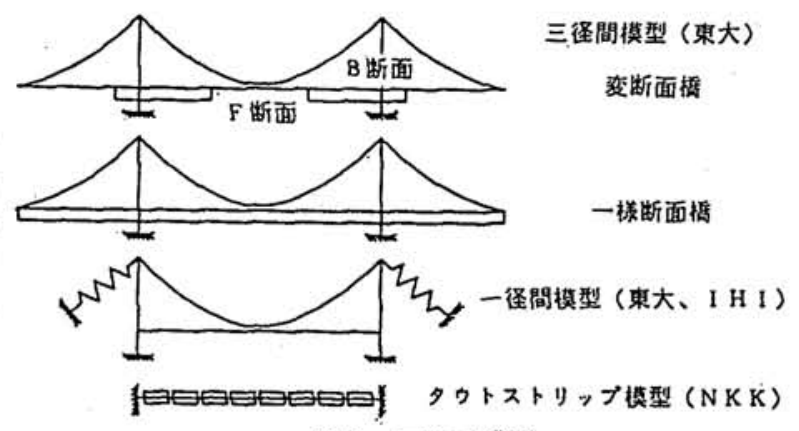

図 2 三次元模型

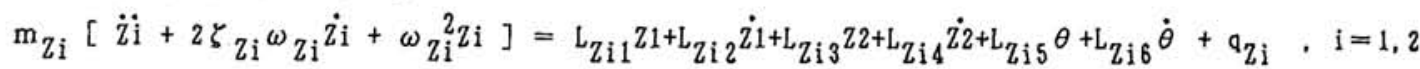

$I_{\theta}\left[\ddot{\theta}+2 \zeta_{\theta} \omega_{\theta} \dot{\theta}+\omega_{\theta}^{2} \theta\right]=L_{\theta 1} Z 1+L_{\theta 2}{ }^{i 1+L}{ }_{\theta 3} Z 2+L_{\theta 4} \dot{Z}_{2+L}{ }_{\theta 5} \theta+L_{\theta 6} \dot{\theta}+q_{\theta}$

ここで、m、I は振動モードを考感した一般化質量（極慣性）である。右辺の第 $1 \sim 4$ 項は一般化動的空気 力項で、一般化動的空気力係数 L は風速、振動数及び迎角の関数である。第 5 項は一般化变動空気力項で、実 験に用いた境界層乱流の特性（図3）と三分力係数を用いて計算した。その際、空カアドミッタンスには平板 を対象としたシアーズ関数簡易式を用いた。また、空間相関関数には振動数係数タイプの指数型を用い、デニ ケイファクターは $\mathrm{u}$, w方向とも $\mathrm{k}=8$ とした。
*1 東大大学院
*2 東大工学部
*3 石川島播磨重工 ( I H I )
*4 横国大工学部
*5 本四公団
*6 日本銅管 ( N K K) 


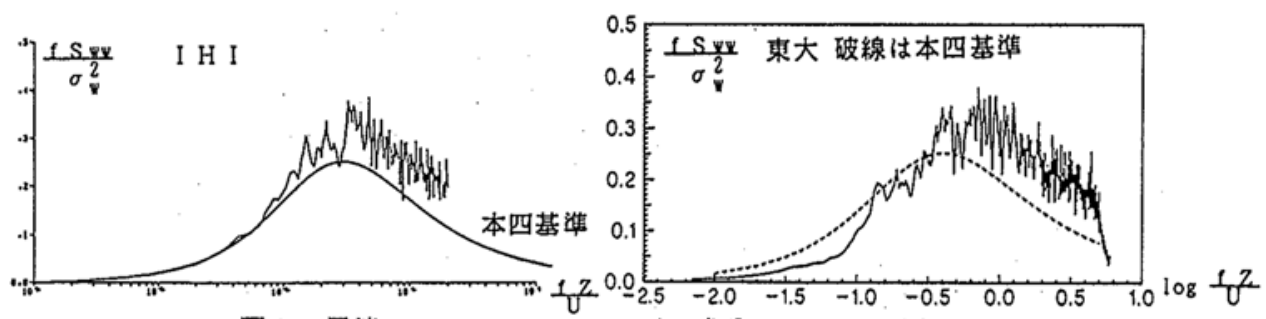

図 3 風速のパワースペクトル（w成分、 $U=3.2 \mathrm{~m} / \mathrm{s}$ )

変動空気力のパワースペクトルを求めて、運動方程式より各モー ドの応答のパワースペクトルを求めた。これを積分して、応答の $\mathrm{R}$ $\mathrm{MS}$ 值 (変预分) を得た。

4. 予測結果 応答の RM S 值について、予剆結果を実験結果と 比較する（図 4) 。I H I、N K Kのケースでは予測の精度がかな り高いことがわかる。東大のヶースにおいて鈶直たわみの予测値が 実験值の 2 倍程度の大きい値となっているが、これは用いた乱流ス ペクトル、すなわち気流の測定に問題があったためではないかと考 えている。再度測定を行なうことを計画している。

動的空気力がガスト応答に与える影響をみるため、(1) : モード間 の連成成分まで動的空気力を考虑した場合、(2) : 動的空気力のモー ド間の連成成分を無視した場合、(3) : 動的空気力を無視した場合、 について I H I のケースを例にとって比較する（図 5 ）。鉛直たわ みでは、(3)の場合、突出して大きな值となっている。(1)(2)の場合ど ちらす比較的実験值に近いが、(2)より (1)の方が実験值に近い。ねじ れにっいては(1) (3)の間にたわみほどの差はみられない。これらの ことから、今回の断面では鉛直たわみ、ねじれのガスト応答の予測 には連成した動的空気力の考虑が必要であるといえる。

フラッター限界風速付近でのねじれの応答の予測值は実験值 に比べ大きな值を示している。原因として、ここで用いた動的 空気力が一様流中のもので、境界層乱流中のとは異なることが 考えられる。

5.あとがき境界層乱流中のガスト応答の予測は、一様流 中の三分力係数、動的空気力係数を使用して、かなり高い精度 で可能であることがわかった。今後、東大の結果についての再 検討を行なう予定である。

謝辞本実験は本四公団耐風委只会（宮田委只長）の指導の すとに行なわれたすのである。

参考文献 1) 岩本ら：土木学会第44回年諩概要集 I-380

2) R.H. Scanlan :

THE ACTION OF FLEXIBLE BRIDGES UNDER WIND, II : BUFFETING THEORY , JSV (1978) 60 (2), 201-211

(1): モート間の速成成分まで 動的空気力を考蝉した埸合

(2) : 娌的空気力のモード間の 連成を無視した場合

(3) : 動的空気力を無視した堨合

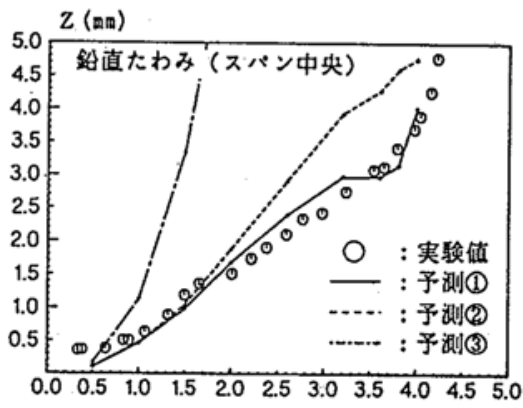

$Z$ (mm), $\theta$ (deg)
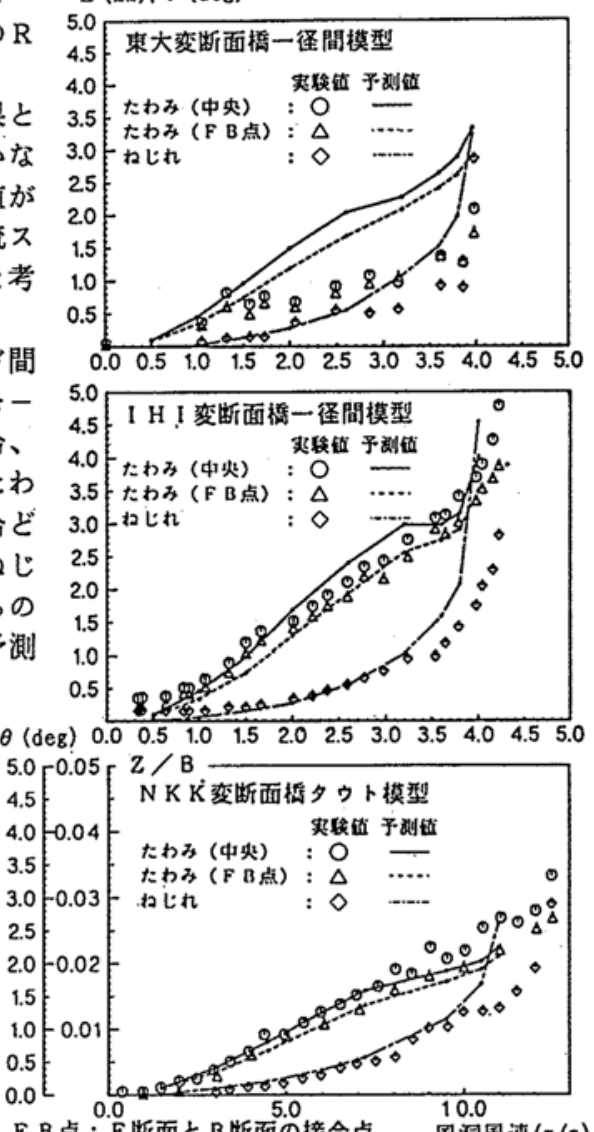

$\mathrm{F} B$ 点 : $\mathrm{F}$ 断面と $\mathrm{B}$ 断面の接合点風洞風速 $(\mathrm{m} / \mathrm{s})$

図 4 予测結果侧（応答の R M S 值） $\theta$ (deg)

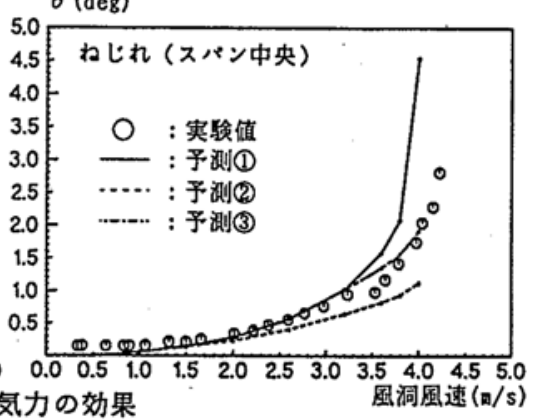

